\title{
Production of Yeast Extract from Whey using Kluyveromyces marxianus
}

\author{
Jean P. de Palma Revillion, Adriano Brandelli and Marco A. Záchia Ayub* \\ Instituto de Ciência e Tecnologia de Alimentos; Universidade Federal do Rio Grande do Sul; 91501-970; C. P. \\ 15090; Porto Alegre - RS - Brasil
}

\begin{abstract}
The yeast Kluyveromyces marxianus CBS 6556 was grown on whey to produce nucleotide-rich yeast extracts. Thermal treatments of cells at 35 or $50^{\circ} \mathrm{C}$ for $15-30 \mathrm{~h}$ resulted in yeast extracts containing about $20 \mathrm{~g} / \mathrm{L}$ protein, with only the second treatment resulting in the presence of small amounts of RNA. In contrast, autolysis in buffered solution was the unique treatment that resulted in release of high amounts of intracellular RNA, being, therefore, the better procedure to produce 5 '-nucletide rich extract with $K$. marxianus.
\end{abstract}

Key words: Cheese whey, yeast extract, 5'-nucleotide, food flavour enhancer

\section{INTRODUCTION}

Whey is produced in large amounts by the cheese industry and is a huge waste disposal problem (Marwana and Kenedy, 1988). Cheese whey has a high biochemical oxygen demand, BOD, (about $30,000-60,000 \mathrm{mg} / \mathrm{L}$ ), depending on the specific cheesemaking process and lactose content (Moresi, 1994). The amount of raw whey annually produced worldwide is estimated to be about $4.0 \mathrm{x}$ $10^{7}$ tons (Tehayadi and Cheryan, 1995), of which up to $3.5 \times 10^{6}$ tons is generated in Brazil (Ponsano and Castro-Gómez, 1995). Aerobic cultivation of microorganisms on cheese whey has been proposed as an alternative to reduce waste disposal problem (Beausejour et al., 1981; BenHassan and Ghaly, 1994) since it can reduce 90$95 \%$ of its BOD (Grubb and Mawson, 1988), resulting in high-added value bio-ingredients for food industry (Belem et al., 1997).

The yield of lactose to biomass can reach $50-57 \%$ (Moresi et al., 1980), which can be optimised if the culture media is supplemented with yeast extract at 0.1 to $5 \%$ (El-Hawary and Mehanna, 1991; Kallel-Mhiri et al., 1994).

Yeast extract is commercially available as either powders or pastes and has been extensively used as flavouring agent by the food industry. It is rich in nucleic acids, consisting of mainly ribonucleic acid (Nagodawithana, 1992). After autolysis and partial hydrolysis of RNA, ribonucleotides such as guanosine 5'-monophosphate (GMP) and inosine 5 '-monophosphate (IMP) may be extracted from the biomass. These substances are efficient flavour enhancers at levels below detection thresholds (Schiffman, 1987). The chemical compounds responsible for flavour enhancement action in crude preparations were found to be predominantly due to monosodium glutamate (MSG), IMP, and GMP (Akiyama et al., 1975). These three flavour enhancers are well known in the food industry and are now commercially available worldwide. They accentuate meaty flavours in foods and have found applications in

\footnotetext{
*Author for correspondence
} 
many savoury products. The world market of flavour enhancers surpasses US\$ 1.1 billion per year (Révillion et al., 2000).

The preparation of yeast extract requires disruption of cell walls. However, among physical, chemical, and enzymatic methods for yeast breakage, autolysis is the only method that appears practical on industrial scale (Orban et al., 1994). Yeast autolysis occurs around a $\mathrm{pH}$ of 5.0 (Béhalová and Beran, 1979). However, during cell autolysis, intracellular RNA normally decomposes to low molecular weight non-flavourizing substances such as nucleosides or puric/pyrimidic bases. Indeed, when autolysis is carried out at $\mathrm{pH}$ lower than 6.0, the GMP formation is very low (Tanekawa et al., 1981). However, $50-80 \%$ of intracellular RNA remained intact when yeast autolysis was developed at a constant $\mathrm{pH}$ range of 6.2-6.4 at $30-60^{\circ} \mathrm{C}$ for $10-30 \mathrm{~h}$ (Tanekawa et al., 1981). In this case, the remaining intracellular RNA could be easily hydrolysed to 5'-nucleotides by the action of phosphodiesterase preparations, obtained from malt roots or fungi, in a manner to obtain an extract rich in flavouring compounds such as GMP or IMP (Nagodawithana, 1992).

Microorganisms such as Candida utilis, Saccharomyces cerevisiae, Bacillus subtilis, Penicillium citrinum, and Micrococcus glutamicus (Belem et al., 1997; Ichii et al., 1993) have been reported to produce ribonucleotides. The yeast Kluyveromyces marxianus has shown great potential for cultivation on whey, due to its $\beta$ galactosidase production when lactose is used as carbon source (Ichaurrondo et al., 1993; Rech et al., 1999). Moreover, K. marxianus has very high growth yields when compared with other yeasts (Castillo, 1990), and it is a GRAS microorganism, being permitted to be cultivated on whey (Dziekak, 1987).

The aim of this work was to investigate the use of cheese whey as a culture medium to produce yeast extract for food use by cultivation of $K$. marxianus.

\section{MATERIALS AND METHODS}

\section{Reagents}

Alcalase $^{\mathrm{TM}}$ 2.4L was from Novo Nordisk (Copenhagen, Denmark). Ribonuclease A, agarose, diethanolamine, bakers yeast RNA type III, were from Sigma Chemical Co. (St. Louis,
USA). 5'-phosphodiesterase was prepared from malt roots as described elsewhere (Tanekawa et al., 1981).

\section{Media composition}

The medium used was made up with $70 \mathrm{~g} \mathrm{~L}^{-1}$ of reconstituted sweet whey powder, obtained from a local dairy industry (Elege Laticinios SA., Lageado, Brazil). Whey powder composition was $71 \%$ lactose, $11.1 \%$ soluble protein, $0.7 \%$ fat, $3 \%$ moisture, and $7.2 \%$ ash.

\section{Whey hydrolysis}

Enzymatic hydrolysis of whey was carried out using $0.1 \%(\mathrm{v} / \mathrm{v})$ Alcalase $2.4 \mathrm{~L}$. The $\mathrm{pH}$ was corrected from 7.0 to 8.5 , and the solution was incubated at $50^{\circ} \mathrm{C}$ for $3-4 \mathrm{~h}$ under agitation. Then, the $\mathrm{pH}$ was adjusted to 5.5, optimum for $K$. marxianus growth. Corrections of $\mathrm{pH}$ were done using food grade $\mathrm{NaOH}$ or citric acid. This avoided protein precipitation during the sterilization process.

\section{Cultivation}

Whey was inoculated with $K$. marxianus CBS 6556 to obtain an initial count of $10^{6}$ cells $/ \mathrm{mL}$. Batch cultivation was carried out on a $2.0 \mathrm{~L}$ stirred tank bioreactor (New Brunswick Scientific, USA). The system was incubated under agitation and sterile aeration of $7 \mathrm{~L} / \mathrm{min}$, which allowed a conversion rate of $0.55 \mathrm{~g}$ biomass per $\mathrm{g}$ lactose consumed (Moresi, 1990). Under these conditions, lactose was completely consumed within $20 \mathrm{~h}$. After cultivation, biomass was recovered by centrifugation at 2,500 $\mathrm{g}$ for $10 \mathrm{~min}$.

\section{Cell concentration}

The cell concentration was estimated by measuring the optical density at $620 \mathrm{~nm}$ and relating the readings to biomass dry weight with a calibration curve. The cells were harvested at $10,000 \mathrm{~g}$ for $5 \mathrm{~min}$ and washed twice with phosphate buffered solution, $\mathrm{pH}$ 6.6.

\section{Mechanical disruption of cell walls}

Mechanical breakage of cell envelope was carried out using a Puc-Vikosator colloidal mill (Kolloldtechnik, Germany). Cell suspensions were treated through a $0.03-0.05 \mathrm{~mm}$ opening for repeated cycles. Cellular envelopes were separated by centrifugation at $10,000 \mathrm{~g}$ for $20 \mathrm{~min}$, the pellet was discarded and the supernatant was used for analysis of protein concentration. 


\section{Yeast autolysis}

A $10 \%(\mathrm{w} / \mathrm{v})$ cell suspension was prepared in 50 $\mathrm{mM}$ diethanolamine buffer $\mathrm{pH}$ 6.4. Ethyl acetate was added to a final concentration of $5 \%(\mathrm{v} / \mathrm{v})$. Cell suspensions were then incubated at 35 or $50^{\circ} \mathrm{C}$ for 15 or $30 \mathrm{~h}$. Yeast autolysates were centrifuged at $10,000 \mathrm{~g}$ for $20 \mathrm{~min}$, the pellet was discarded and the supernatants were used for further analysis. Part of the supernatant was spraydried at $135-139^{\circ} \mathrm{C}$ with flow rate of $2 \mathrm{~mL} / \mathrm{min}$ in a bench Büchi Labortechnik spray-drier (Büchi Labortechnik, Switzerland).

\section{Enzyme and heat treatments}

Part of yeast autolysates were incubated at $95^{\circ} \mathrm{C}$ for $1 \mathrm{~h}$, and then RNA hydrolysis was accomplished by enzymatic action of $20 \%(\mathrm{w} / \mathrm{v})$ 5 '-phosphodiesterase (Tanekawa et al., 1981) for $10 \mathrm{~h}$ at $55^{\circ} \mathrm{C}$. Enzyme was inactivated by thermal treatment at $95^{\circ} \mathrm{C}$ for $5 \mathrm{~min}$.

\section{Analytical methods}

Protein concentration was measured by the Folin phenol reagent method (Scopes, 1994). Carbohydrates were determined by the phenol sulphuric acid method (Chaplin, 1986). The RNA concentration was estimated by spectrophotometry, as described elsewhere (Delaney et al., 1975). Yeast extract composition analysis was carried out by AOAC methodology (AOAC, 1984).

\section{Gel electrophoresis of $R N A$}

RNA released by the different autolysis treatments was analysed by agarose gel electrophoresis. Samples were applied on $1.2 \%$ agarose gels containing $1 \mu \mathrm{g} \mathrm{ml}^{-1}$ ethydium bromide and run at $100 \mathrm{~V}$ for $2 \mathrm{~h}$ in TEB buffer $\left(10 \mathrm{~g} \mathrm{~L}^{-1}\right.$ Tris, $1 \mathrm{~g} \mathrm{~L}^{-1}$ EDTA, $5.5 \mathrm{~g} \mathrm{~L}^{-1}$ boric acid). Gels were observed under UV light.

\section{RESULTS AND DISCUSSION}

\section{Whey hydrolysis}

The use of Alcalase ${ }^{\mathrm{TM}} 2.4 \mathrm{~L}$, a broad range protease produced by Bacillus lichineformis, was effective in hydrolyzing whey proteins. In this process, soluble whey protein $(0.8-1.1 \%$ weight $)$ was hydrolysed to amino acids and peptides, which were readily assimilated by yeast. Therefore, whey supplementation with a nitrogen source was unnecessary. In fact, yeast extract has been already used as supplementation for nucleotide production by $K$. marxianus (Belem et al., 1997). Alcalase is widely used in the food industry and its hydrolysates are recognized to have a lower bitterness when compared to other proteases (Lahl and Braun, 1994).

\section{Growth of K. marxianus on whey}

Microbial growth and lactose comsumption were followed during fermentation. A typical growth curve is shown in Fig. 1. The yeast $K$. marxianus grew well in whey reaching the stationary growth phase after $15 \mathrm{~h}$. At this time, carbohydrate consumption reached minimum values. This indicated that whey disposal problems would be effectively reduced by $K$. marxianus fermentation. The maximum specific growth rate, $\mu_{\max }$, the doubling time, $t_{d}$, the yield of biomass formation, $\mathrm{Y}_{\mathrm{X} / \mathrm{S}}$, calculated at the final growth phase were $0.62 \mathrm{~h}^{-1}, 1.12 \mathrm{~h}, 0.30 \mathrm{~g}$ cell/g lactose, respectively. The growth parameters were similar to those previously reported for $K$. marxianus grown on whey (Rech et al., 1999).

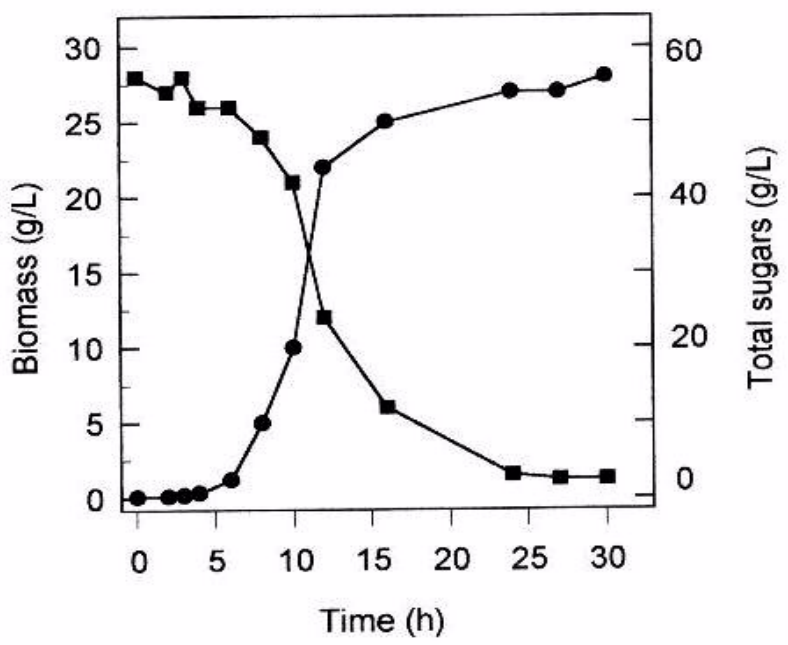

Figure 1 - Growth of $K$. marxianus on whey. Biomass generated and (ם) lactose comsumption. General growth conditions are described in the text.

\section{Mechanical disruption of cell envelope}

The mechanical cell disruption of yeast causes the release of hydrolytic enzymes, inducing the autolytic process (Babayan and Bezrukov, 1985). The colloidal mill is a widely studied mechanical system to rupture cells, presenting the best 
possibilities for industrial utilization (van Gaver and Huyghebaert, 1989). We demonstrated that a thermal pre-treatment $\left(55^{\circ} \mathrm{C} / 24 \mathrm{~h}\right)$ of yeast cells eliminates the need for homogenisation with a colloidal mill to release the intracellular components, since this did not add to the final protein content of extracts (results not shown). Use of ultrasound, glass beads, or a colloidal mill did not result in significant differences in cell envelope rupture of $S$. cerevisiae at different temperatures (Révillion et al., 1996). Treatment of $K$. fragilis biomass in concentrations ranging from $80-110 \mathrm{~g} / \mathrm{L}$, at $51-54^{\circ} \mathrm{C}$ for $8 \mathrm{~h}$, was the most efficient to induce cell autolysis with solubilization of $51.5 \%$ protein (Orban et al., 1994). Those authors showed that previous cell treatment with $5 \%$ sodium chloride, or mechanical rupture of cells did not modify the autolytic process. However, Baldwin and Robinson (Baldwin and Robinson, 1994) described the cell rupture with utilization of a two-step process: enzymatic treatment of cell wall with the enzyme Zimolase 20T, followed by cell disruption with homogeniser. They also concluded that 6 cycles at
$95 \mathrm{MPa}$ with enzymatic pre-treatment led to almost $95 \%$ cell rupture. It is relevant to consider that in their research the authors used the yeast Candida utillis ATCC 9226, which presents higher mechanical resistance to disruption than $S$. cerevisiae and $K$. marxianus.

\section{Yeast autolysis}

In this work, assays were carried out varying some factors that induced the autolysis process, and then soluble protein concentration was measured in the extract obtained. To evaluate the influence of such factors on the efficiency of intracellular content release, $K$. marxianus cells were incubated at 35 or $50^{\circ} \mathrm{C}$ for 15 or $30 \mathrm{~h}$. The results are shown in the Table 1. Thermal treatment did not influence significantly the release of protein. Maximum soluble protein was observed at $35^{\circ} \mathrm{C}$ for $15 \mathrm{~h}$. This could be explained considering that ethyl acetate $(5 \%, \mathrm{v} / \mathrm{v})$ was an efficient permeabilizant agent, resulting in no important differences among the treatments.

Table 1 - Release of soluble protein by different autolysis procedures*

\begin{tabular}{lcc}
\hline Treatment & Soluble protein $(\mathbf{g} / \mathbf{L})$ & Yield (g/g biomass) \\
\hline Control & $16.4 \pm 0.4$ & 0.66 \\
$35^{\circ} \mathrm{C} / 15 \mathrm{~h}$ & $19.4 \pm 0.4$ & 0.77 \\
$35^{\circ} \mathrm{C} / 30 \mathrm{~h}$ & $18.8 \pm 1.0$ & 0.75 \\
$50^{\circ} \mathrm{C} / 15 \mathrm{~h}$ & $18.8 \pm 0.5$ & 0.75 \\
$50^{\circ} \mathrm{C} / 30 \mathrm{~h}$ & $18.4 \pm 0.2$ & 0.74 \\
\hline
\end{tabular}

* Results are the mean \pm s.e.m. of triplicate assays.

Table 2 - Composition of $K$. marxianus extract*

\begin{tabular}{lc}
\hline Component & $\mathbf{m g ~ g}^{-\mathbf{1}}$ \\
\hline Crude protein & 520.0 \\
Fat & 5.4 \\
Ash & 72.0 \\
Moisture & 54.0 \\
Carbohydrate(difference) & 348.6 \\
\hline
\end{tabular}

* Results are the average of triplicate samples.

In addition, it was relevant to observe that the thermal treatments developed in the steps of extraction and hydrolysis did not result in insolubilization of nitrogen compounds, which was important in obtaining cell extracts rich in low MW nitrogen compounds and nucleotides.

The nitrogen release from yeast cells ( $S$. cerevisiae) in a buffered solution at $\mathrm{pH} 5.0$ was faster when incubated at 55 and $44^{\circ} \mathrm{C}$, than at $36^{\circ} \mathrm{C}$ (Feuillat and Charpentier, 1982). After $4 \mathrm{~h}$ of heating at $55^{\circ} \mathrm{C}$, there was no increase in the concentration of amino acids. However, at lower temperatures, the autolysis followed up to $48 \mathrm{~h}$, and the nitrogen concentration released at $36^{\circ} \mathrm{C}$ were higher than those observed at $55-44^{\circ} \mathrm{C}$. This kinetics suggested that first there occurred a passive release of nitrogen compounds from cells to media, followed by enzymatic action, which was rapidly inhibited 
at elevated temperatures. These data are in agreement to the ones observed in our work.

\section{Composition of $K$. marxianus extract}

The general composition of $K$. marxianus extract grown on whey is given in Table 2. K. marxianus extract contained a high content of crude protein and low fat and moisture contents. The product had a good level of crude protein (ca $50 \%$ ) and a low ash content (ca. $7 \%$ ). Both these factors are important for products intended for feed or food use. The composition of yeast products derived from whey revealed that generally these products were high in crude protein (Delaney et al., 1975).

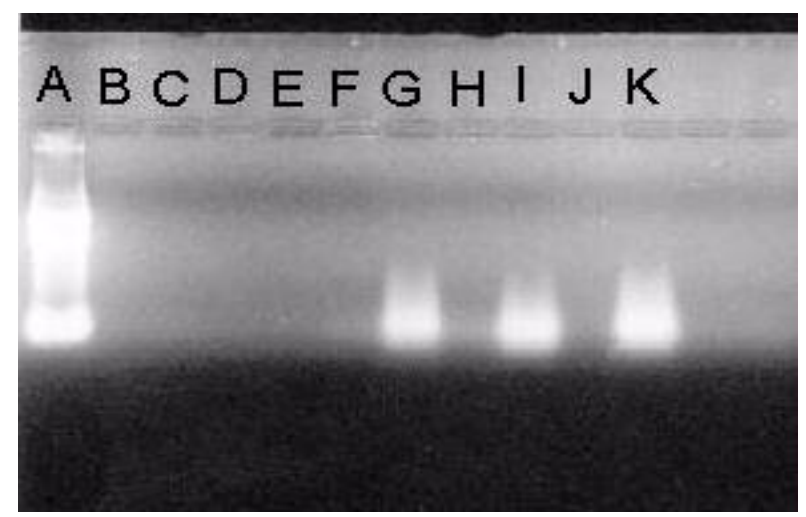

Figure 2 - Analysis of $K$. marxianus extracts by agarose gel electrophoresis. Samples of yeast extracts obtained by autolysis at $35^{\circ} \mathrm{C}$ for $15 \mathrm{~h}$ (lanes B,C) or 30 $\mathrm{h}$ (lanes D,E); or autolysis at $50^{\circ} \mathrm{C}$ for $15 \mathrm{~h}$ (lanes $\mathrm{F}, \mathrm{G}$ ) or $30 \mathrm{~h}$ (lanes H,I). Lanes B,D,F,H represent samples treated with malt root 5'-phosphodiesterase. Lane A, standard RNA; lanes J,K control samples treated and non-treated with 5'-phosphodiesterease, respectively.

\section{Nucleotide-rich extract}

Qualitative analysis of intracellular RNA release was carried out by agarose gel electrophoresis (Fig. 2). Analysis of RNA bands after different treatments indicated that low MW fragments were produced after autolysis at $50^{\circ} \mathrm{C}$ for $30 \mathrm{~h}$, and bands corresponding to high molecular weight $28 \mathrm{~S}$ and 18S RNA were not detected.

The amount of RNA in cell extract was determined by spectrophotometry. Nonhydrolysed RNA was detected in the preparations corresponding to controls, and after autolysis at $50^{\circ} \mathrm{C}$ for both 15 and $30 \mathrm{~h}$ (Table 3 ). The presence of intact RNA was coincident with the gel electrophoresis analysis. The autolytic treatment at $50^{\circ} \mathrm{C} / 30 \mathrm{~h}$ resulted in a higher amount of RNA. In this case, no detectable amounts of RNA were observed after further treatment with malt roots 5'phosphodiesterase, suggesting their hydrolysis to nucleotides.

Samples treated at $35^{\circ} \mathrm{C}$ did not shown detectable amounts of RNA, indicating that hydrolysis during processing has occurred. These results indicate that the RNA released during the autolytic treatment was completely hydrolysed. These results were in agreement with observations made by Belem et al (1997), who observed that maximum production of $5^{\prime}$-nucleotides from $K$. marxianus grown on whey was obtained by a $12 \mathrm{~h}$ treatment at $50^{\circ} \mathrm{C}$ and $\mathrm{pH} 6.5$ and that the use of phosphodiesterase treatment for selective conversion of RNA into 5'-nucleotides, increased the final content of flavour enhancers. It was expected to obtain RNA content in the range of $10-15 \%$ of cell dry weight (Ogata, 1975).

Table 3 - Release of ribonucleic acid by different autolysis procedures

\begin{tabular}{lcc}
\hline Treatment & Ribonucleic acid (mg/L) & Yield (mg/g biomass) \\
\hline Control & $375 \pm 40$ & 15.0 \\
$35^{\circ} \mathrm{C} / 15 \mathrm{~h}$ & $\mathrm{ND}$ & - \\
$35^{\circ} \mathrm{C} / 30 \mathrm{~h}$ & $\mathrm{ND}$ & - \\
$50^{\circ} \mathrm{C} / 15 \mathrm{~h}$ & $285 \pm 30$ & 11.4 \\
$50^{\circ} \mathrm{C} / 30 \mathrm{~h}$ & $430 \pm 10$ & 17.2 \\
\hline
\end{tabular}

* Results are the mean \pm s.e.m. of triplicate assays.

In conclusion, the autolysis in buffered solution at $\mathrm{pH} 6.4 / 50^{\circ} \mathrm{C} / 30 \mathrm{~h}$ was the best condition, which resulted in the release of intracellular RNA, being adequate to produce 5 'nucleotide-rich extracts with $K$. marxianus grown on whey. In addition, the use of malt extract $\left(5^{\prime}\right.$-phosphodiesterase preparation) was efficient to hydrolyse the RNA released during the autolysis. 


\section{Considerations to plant scale process}

A diagram for 5 -nucleotide productive process is suggested in Figure 3. Whey must be stored in refrigerated tanks to avoid denaturation of protein and other compounds suitable for $K$. marxianus growth, and also to inhibit the formation of undesired metabolites produced by other microorganisms. It is recommended to use stainless steel tanks provided with chilling and agitation devices. We suggest that the enzymatic hydrolysis should be conducted in fermentation tanks, because the need for agitation and heating are common to both steps and the thermal process is equivalent to pasteurisation process. Selfcleaning or nozzle-bowl centrifuges can be used for classification and yeast extract concentration may be conducted in flash vacuum concentrators and spray-dried if a final dry product is desired.

Whey storage
$\downarrow$
Enzymatic hydrolysis
$\downarrow$
Inoculation of raw material
$\downarrow$
Fermentation
$\downarrow$
Centrifugation of biomass
$\downarrow$
Thermal induction of autolysis and/or Mechanical
rupture of cells
$\downarrow$
5'-nucleotide production
$\downarrow$
Elimination of cell debris
$\downarrow$
Concentration of cell extract
$\downarrow$
Drying of cell extract

Figure 3 - Proposed diagram for plant productive process flow.

\section{RESUMO}

A levedura Kluyveromyces marxianus CBS 6556 foi cultivada em soro de queijo para produzir extrato celular rico em nucleotídeos. O soro foi pré-tratado com Alcalase ${ }^{\mathrm{TM}}$. K. marxianus foi inoculada e cultivada em batelada sob agitação e aeração de $7,0 \mathrm{~L}$ ar/min por $20 \mathrm{~h}$ em biorreator de $2 \mathrm{~L}$ de volume. A biomassa resultante foi submetida a diferentes tratamentos para obter os extratos enriquecidos. Tratamento térmico das células a $35^{\circ} \mathrm{C}$ ou $50^{\circ} \mathrm{C}$ por $15-30 \mathrm{~h}$ resultou em extratos contendo cerca de $20 \mathrm{~g} / \mathrm{L}$ de proteína, mas apenas com o segundo tratamento apresentando pequenas quantidades de RNA, medido por eletroforese de gel e espectrofotometria. Em contraste, tratamento autolítico em solução tamponada foi o único a resultar na liberação de importantes quantidades de RNA intracelular, sendo portanto, o mais adequado para a produção de 5'-nucleotídeos a partir de extratos celulares de $K$. marxianus crescidos em soro de queijo.

\section{REFERENCES}

Akiyama, S.; Doi, M.; Arai, Y.; Nakoa, Y. and Fukuda, H. (1975), Production of yeast biomass. US Patent $3,909,532$.

AOAC (1984), Official Methods of Analysis. $17^{\text {th }}$ ed. Association of Official Analytical Chemists, Washington.

Babayan, T. L. and Bezrukov, M. G. (1985), Autolysis in yeasts. Acta Biotechnol., 5, 129-136.

Baldwin, C. V. and Robinson, C. W. (1994), Enhanced disruption of Candida utilis using enzimatic pretreatment and high pressure homogenization. Biotechnol. Bioeng., 4346-56.

Beausejour, D.; Leduy, A. and Ramalho, R. (1981), Batch cultivation of Kluyveromyces fragilis in cheese whey. Can. J. Chem. Eng., 56522-526.

Béhalová, B. and Beran, K. (1979), Activation of proteolytic enzymes during autolysis of disintegrated baker's yeast. Folia Microbiologica, 24455-461.

Belem, M. A. F.; Gibbs, B. F. and Lee, B. H. (1997), Enzymatic production of ribonucleotides from autolysates of Kluyveromyces marxianus grown on whey. J. Food Sci., 62, 851-857.

Ben-Hassan, R. M. and Ghaly, A. E. (1994), Continuous propagation of Kluyveromyces fragilis in cheese whey for pollution potential reduction. Appl. Biochem. Biotechnol., 47, 89-104.

Castillo, F. J. (1990), Lactose metabolism by yeasts. In: Verachtert, H. and Mot, R. (ed.).Yeast Biotechnology and Biocatalysis. New York : Marcel Dekker Inc. pp.297-320.

Chaplin, M. F. (1986), Monosaccharides. In: Chaplin, M. F. and Kennedy, J.F. (ed.). Carbohydrate analysis. Oxford : IRL Press. pp. 1-36.

Delaney, R. A. M.; Kennedy, R. and Walley B. D. (1975), Composition of Saccharomyces fragilis biomass grown on lactose permeate. J. Sci. Food Agric., 26, 1177-1186.

Dziekak, J. D. (1987), Yeast and Yeast derivatives, definitions, characteristics and processing. Food Technol., 41104-112. 
El-Hawary, F. I. and Mehanna, A. S. (1991), Production of single cell protein from yeast grown in whey. Acta Alimentaria, 20, 205-213.

Feuillat, M. and Charpentier, C. (1982), Autolysis of yeast in champagne. Am. J. Enol. Vitic., 33, 6-13.

Grubb, C. F. and Mawson, A. J. (1988), Effects of elevated solute concentrations on the fermentation of lactose by Kluyveromyces marxianus Y-113. Biotechnol. Lett., 15621-626.

Ichaurrondo, V. A.; Yantorno, O. M. and Voget, C. E. (1993), Yeast growth and $\beta$-galactosidase production during aerobic batch cultures in lactose-limited synthethic medium. Process. Biochem., 29, 47-54.

Ichii, T.; Takehara, S.; Konno, H.; Ishida, T.; Sato, H.; Suzuki, A. and Yamazumi, K. (1993), Development of a new commercial-scale airflit fermentor for rapid growth of yeast. J. Ferment. Bioeng., 75, 375-379.

Kallel-Mhiri, H.; Valance, C.; Engasser, J. M. and Miclo, A. (1994), Yeast continuous mixed cultures on whey permeate and hydrolised starch. Process. Biochem., 29, 381-386.

Lahl, W. J. and Braun, S. D. (1994), Enzymatic production of protein hydrolysates for food use. Food Technol., 48, 68-71.

Marwana, S. S. and Kennedy, J. F. (1988), Review, whey pollution problem and potencial. Int. J. Food Sci. Technol., 23, 323-336.

Moresi, M.; Colicchio, A. and Sansovini, F. (1980), Optimization of whey fermentation in a jar fermenter. Eur. J. Appl. Microbiol. Biotechnol., 9, 173-183.

Moresi, M.; Trunfio, A. and Parente, E. (1990), Kinetics of continuous whey fermentation by $K$. fragilis. J. Chem. Technol. Biotechnol., 49, 205-222.

Moresi, M. (1994), Cost/benefit analysis of yeast and yeast autolysate production from cheese whey. Italian J. Food Sci., 6, 357-370.

Nagodawithana, T. (1992), Yeast-derived flavours and flavour enhancers and their probable mode of action. Food Technol., 46, 138-144.

Ogata, K. (1975), The microbial production of nucleic acid related compounds. Adv. Appl. Microbiol., 19, 209-247.
Orban, E.; Quaglia G. B.; Casini, I. and Moresi, M. (1994), Effect of temperature and yeast concentration on the autolysis of Kluyveromyces fragilis grown on lactose based media. J. Food Eng., 21, 245-261.

Ponsano, E. H. G. and Castro-Gómez, R. J. H. (1995), Fermentação do soro de queijo por Kluyvemomyces marxianus como uma alternativa tecnológica para a redução de sua capacidade poluente. Ciencia Tecnol. Aliment., 15, 170-173.

Rech, R.; Cassini, C. F.; Secchi, A. and Ayub, M. A. Z. (1999), Utilization of protein-hydrolyzed cheese whey for production of $\beta$-galactosidase by Kluyveromyces marxianus. J. Ind. Microbiol. Biotechnol., 23, 91-96.

Révillion, J. P. P.; Pibernat, C. C.; Giuliani, J. and Ayub, M. A. Z. (1996), Utilização de extratos de leveduras Saccharomyces cerevisiae na elaboração de vinhos espumantes. Ciência Tecnol. Alim., 16, 196-205.

Révillion, J. P. P.; Brandelli, A. and Ayub, M. A. Z. (2000), Production of yeast extracts from whey for food use, market and technical considerations. Ciência Tecnol. Alim., 20, 246-249.

Schiffman, S. S. (1987), Recent developments in taste enhancement. Food Technol., 4172-73.

Scopes, R. K. (1994), Protein purification. Principles and practice. $3^{\text {rd }}$ ed. New York: Springer-Verlag. 380 pp.

Tanekawa, T.; Takashima, H. and Hachiya, T. (1981), Production of yeast extract containing flavouring. US patent 4,303,680.

Tehayadi, S. and Cheryan, M. (1995), Lactic acid from cheese whey permeate. Productivity and economics of a continuous membrane bioreactor. Appl. Microbiol. Biotechnol., 43, 242-248.

van Gaver, D. and Huyghebaert, A. (1989), Extraction of oligopeptides and proteins from bakers yeast cells by airdrying autolysis. Belgian J. Food Chem. Biotechnol., 44, 83-87. 